\title{
The immunopathology of erythema nodosum leprosum: the role of extravascular complexes
}

\author{
MARIAN J RIDLEY \& D S RIDLEY \\ Hospital for Tropical Diseases, London NW1 OPE
}

Received for publication 8 August 1982

\begin{abstract}
Summary Skin biopsies of 20 patients with erythema nodosum leprosum were studied histologically, by acid-fast, silver and immunological methods for the demonstration of bacterial antigen, and by immuno-peroxidase for a variety of immunological factors. The results were compared with those in 10 non-reacting lepromatous patients.

At the centre of the ENL lesions there was always disintegration of macrophages and release of bacterial antigen, comprising cell walls and particulate or diffuse components of Mycobacterium leprae. These products were found to combine first with $\operatorname{IgM}$, later with $\mathrm{IgG}$, which together with complement components of the classical pathway were present at the same sites. These complexes were found both extracellularly and in neutrophils and macrophages, and were constant features of acute stage lesions. C-reactive protein and B-lipoprotein were present in varying amounts and were associated partly with connective tissue. It is thought that CRP, and the related SAP, may be factors in the disruption or repair of elastic and collagen, which are conspicuous in some ENL lesions. The results support the view that ENL is an immune complex phenomenon, possibly self-perpetuating, occurring at the site of breakdown of small lepromatous granulomas. The immune complexes are extravascular and in this respect ENL differs from the classical 'serum sickness' described by Arthus.
\end{abstract}

\section{Introduction}

Erythema nodosum leprosum (ENL) is a reactional episode of lepromatous leprosy where large amounts of mycobacterial antigen and of corresponding antibodies provide evidence for an immune complex aetiology. Support for this hypothesis comes from disease manifestations, ${ }^{1}$ from the binding of $\mathrm{C}_{1} \mathrm{q}$ of sera from patients with ENL, ${ }^{2-5}$ and from the deposition of $\mathrm{C}_{3}$ and immunoglobulins $\mathrm{IgG}$ and $\mathrm{IgM}$ in glomeruli. ${ }^{6,7} \mathrm{ENL}$ has been regarded as a clinical manifestation of the Arthus reaction because of the demonstration of granular deposits of $\mathrm{C}_{3}$ and immunoglobulin in the lesions of some patients. ${ }^{8}$ The same group of workers in subsequent reports ${ }^{9} 10$ concluded that the reaction was due to the trapping of 
circulating immune complexes. No mycobacterial antigen was demonstrated in the lesion. A recent communication ${ }^{11}$ casts doubt on the analogy that has been made between ENL reactions and serum sickness because ENL reactions are seen to centre round the granuloma. ${ }^{12}$ Extravascular formation of immune complexes is a more likely suggestion ${ }^{5,11}$ but direct evidence is lacking.

Following our application of the immunoperoxidase technique to the study of the pathological response across the spectrum of leprosy, ${ }^{13}$ and to the mechanism of granuloma development of the two polar groups ${ }^{14}$ we decided to apply this technique to study the pathogenesis of ENL.

\section{Material and methods}

Twenty patients with ENL were included in the study. They comprised 10 cases seen at the Medical Research Council Unit at Sungei Buloh, Malaysia or at the Hospital for Tropical Diseases in London, and 10 seen in Papua New Guinea. The controls were biopsies from 10 patients from Malaysia and Ethiopia who had non-reacting lepromatous leprosy (6 untreated, active and 4 treated and in regression).

Biopsies were fixed in formol-mercuric chloride acetic acid fixative (FMA), used routinely for skin biopsies in leprosy over many years, ${ }^{15}$ which is ideal for the immunoperoxidase technique. ${ }^{16}$ They were processed for routine examination by haematoxylin eosin and a modified Fite-Faraco stain for acid-fast bacilli. Serial paraffin sections were cut at $4 \mu \mathrm{m}$, air dried and stored for use. Excessive heat was avoided in all stages of preparation of tissues. Other stains included Heidenhain's iron haematoxylin, PAS, Baker's acid haematin for phospholipids, MSB for fibrin, Gomori-Grocott methenamine silver, Gomori's reticulin, Verhoeff's elastic and Perl's reaction. Cryostat sections were used for demonstrating neutral fats and cholesterol.

The immunoperoxidase method of Sternberger ${ }^{17}$ was used with modifications. Trypsin was not an advantage either for specificity or strength with the FMA fixative and was omitted. The method and optimal dilutions have been described previously. ${ }^{13,14}$

Antisera were raised without the aid of Freund's complete adjuvant and were obtained from DAKO (Mercia Brocades, Watford). Their specificity has been described by numerous workers and reviewed recently. ${ }^{18}$ They included immunoglobulins IgG, IgM, IgA, IgE, complement components $\mathrm{C}_{3}, \mathrm{C}_{4}, \mathrm{C}_{1} \mathrm{q}, \mathrm{C}_{3} \mathrm{~d}$ lysozyme, coagulation protein plasminogen, protease inhibitors $\alpha_{1}$-antitrypsin, $\alpha_{2}$-macroglobulin, and Mycobacterium BCG. (Antiserum to Mycobacterium leprae an

Antiserum to acute phase reactants $\mathrm{C}$-reactive protein (CRP), serum amyloid $\mathrm{P}$ factor (SAP) and low density $\beta$-lipoprotein (LDL) were a gift from Dr M B Pepys, London, who also gave us pure CRP and SAP for controls. 
One control section was stained for endogenous peroxidase by a mixture of diaminobenzidine hydrochloride and peroxide. Other controls included normal rabbit serum in place of specific antiserum and staining after absorption of the antibody by the antigen. This was possible with $\operatorname{IgG}, \operatorname{IgM}$, lysozyme, $\alpha_{1}$-antitrypsin (Sigma) CRP and SAP (Dr M B Pepys) and with BCG (Glaxo, vaccine). The soluble antigens were diluted $1 / 10$ in Tris buffer mixed and incubated for $20 \mathrm{~min}$ with an equal volume of antiserum before use. Five $\mu \mathrm{g} / \mathrm{ml}$ BCG (vaccine) was added to the BCG antiserum incubated, centrifuged, filtered and used. Finally the use of these antisera to determine different immunological responses in the various groups of the leprosy spectrum ${ }^{13}$ provided a control within the system.

\section{Results}

The reaction of ENL takes place in small well defined granulomas typical of regressing lepromas. They may be superficial or deep in the skin or in the subcutaneous fat. The early reaction shows scattered accumulations of foamy macrophages in an advanced state of decay and varying numbers of neutrophils in close association with them (Figure 1). In the acute phase mast cells and moderate numbers of plasma cells are present. The infiltrate appears massive in some areas, being situated centrally within the granuloma and irregularly scattered among the fat lobules of the subcutis. The fibrous septa between sweat ducts is often the seat of reaction and neutrophil infiltration. In some cases there is significant involvement of blood vessels, with fibrinoid change in the intima of small vessels, and in medium sized veins oedema and invasion of the vessel walls by inflammatory cells. The serous fibrinous exudate stains weakly with PAS indicating the presence of mucopolysaccharides. Fibrinoid connective tissue stains more darkly with PAS and is strongly positive for fibrin.

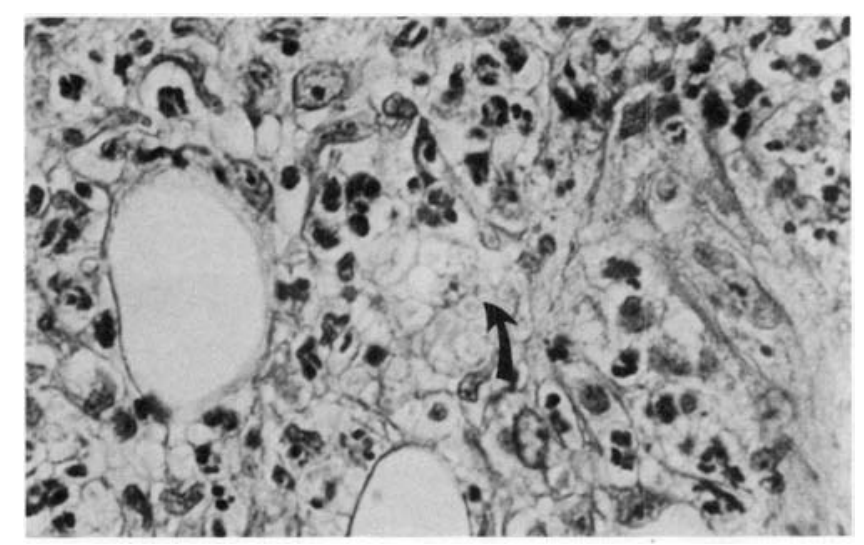

Figure 1. Polymorph neutrophil infiltration, centred on disintegrating macrophages $(\uparrow)$ containing bacterial debris in ENL lesion. $\mathrm{H}+\mathrm{E} . \times 525$. 
In the later stage of the reaction, after the neutrophil infiltration has receded, there are few remaining intact foam cells. Haemosiderin is often demonstrable. Residual accumulations of phagocytic vacuoles are invaded by B lymphocytes and plasma cells producing IgG and IgM, the numbers of which are increased.

THE GRANULOMA IN ENL

\section{Macrophages}

Macrophages involved in the acute reaction are large, foamy and degenerate. Iron haematoxylin shows cell membranes in variable states of preservation, those at the centre being most indistinct. Appropriate staining shows copious neutral fat, with irregular accumulations of phospholipid and glycoproteins present on the inner surface of the phagocytic vacuole. When ENL reactions take place in the superficial dermis, the macrophages of ten appear as single large rounded multinucleated cells, the cytoplasm of which is reduced to a single layer confluent with the cell membrane. The single large central vacuole within the cell is filled with a 'mat' of degenerating acid-fast debris. The macrophage cell membrane is often invaded by inflammatory cells indicating that it is unstable and degenerate, and it is these cells which participate most regularly in the reactions (Figure 2).

Lysozyme is present in all macrophages and in neutrophils; phagocytic vacuoles of degenerating foam cells can readily be identified by its presence. Similarly plasminogen and $\alpha_{1}$-antitrypsin and $\alpha_{2}$-macroglobulin are abundant, bound within cells containing bacillary debris. These inflammatory mediators are more marked in the reactive areas than in non-reacting areas of the lesion. Endogenous peroxidase is not demonstrated in macrophages.

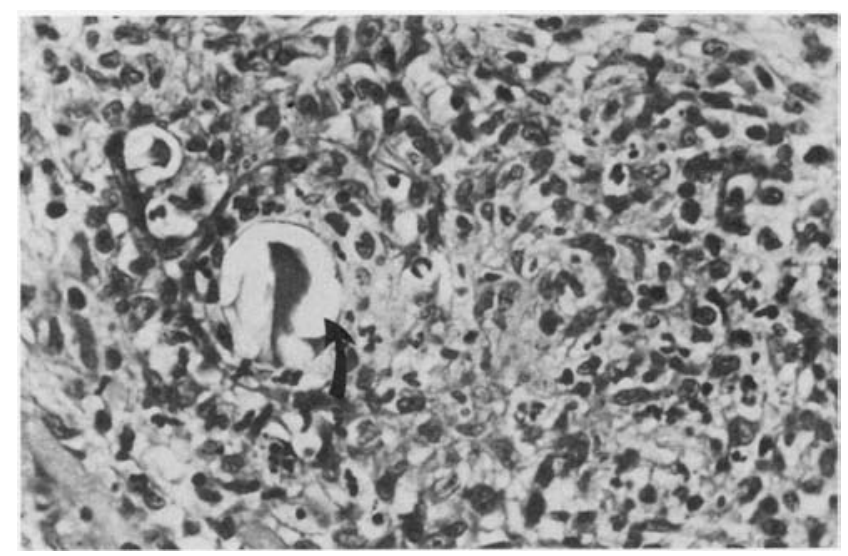

Figure 2. Disintegrating phagocytic vacuoles with mat of bacterial debris $(\uparrow)$ at the centre of a focus of neutrophil infiltration. $\mathrm{H}+\mathrm{E} \times 350$. 


\section{Mycobacterium leprae antigen}

In the acute reaction the most striking feature is the presence of bacillary products adherent to the plasma membrane of phagocytic vacuoles of degenerating foamy macrophages. With the disintegration of the cells and the rupture of the vacuole there is a release of bacterial debris into the intercellular space. Elsewhere this debris can be seen within the vacuoles as well as on the cell membrane. Throughout the reacting lesion it takes a variety of forms. It may be solid staining rods, or short fragments and granules, or it may be diffuse with no recognizable structure. Sometimes it appears in clumps. These various forms can be identified only by the use of special staining methods, as indicated in Table 1. In general the

Table 1. The appearance of bacterial forms and bacterial antigen in an ENL lesion by different staining methods

\begin{tabular}{lcccc}
\hline \multicolumn{1}{c}{ Stain } & Solid & $\begin{array}{c}\text { Fragmented } \\
\text { or granular }\end{array}$ & $\begin{array}{c}\text { Clumped } \\
\text { debris }\end{array}$ & $\begin{array}{c}\text { Diffuse } \\
\text { 'soluble' }\end{array}$ \\
\hline ZN & - & $\mathrm{m} ø+$ & + & - \\
Rabbit anti-BCG & - & $\mathrm{m} ø+$ & - & $\mathrm{m} ø+$ \\
Methenamine silver & $\mathrm{m} \varnothing+++$ & - & $\mathrm{m} \varnothing+++$ & $\mathrm{n}+++$ \\
\hline
\end{tabular}

mø, macrophages; n, neutrophils; AFB, acid-fast bacilli.

largest amount of bacterial debris is demonstrated by impregnation with silver (Figure 3), moderate amounts with BCG antiserum and least of all with Ziehl-Neelsen. In the same preparation at the periphery of the granuloma the macrophages are better preserved, and contain fragmented and granular bacilli by acid-fast stains or solid rods by silver. This appearance is also seen elsewhere in non-reacting parts of the lesion. Neutrophils, particularly in the area of marked reaction, stain diffusely by silver and by anti-BCG antiserum (Figures 4 and 5). They contain no acid-fast material. Thus detectable acid-fast material is more persistent in macrophages than in neutrophils, probably on account of particle size. It appears that only a diffuse or 'soluble' but non-acid-fast bacterial product is present in neutrophils.

\section{Acute phase reactants and $\mathrm{M}$. leprae}

In non-reacting areas CRP is closely bound to granular acid-fast bacilli. In reacting areas the macrophages contain clumps of CRP positive material. This material is not seen in neutrophils. SAP occurs as dark granular clumps or it is finely dispersed around the phagocytic vacuoles of macrophages. It is also seen in 


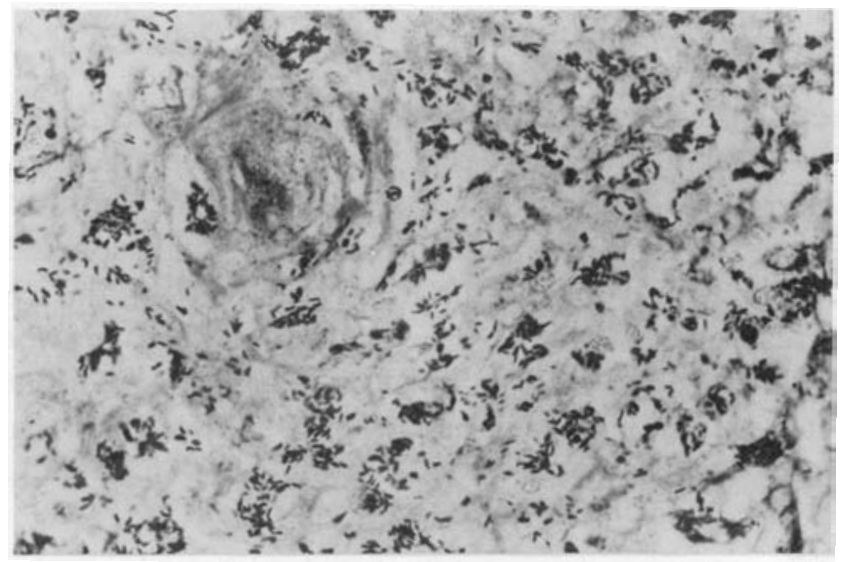

Figure 3. Bacterial cell walls in lepromatous granuloma of ENL lesion. (Acid-fast forms were scanty and mostly non-solid.) Methenamine silver. $\times 525$.

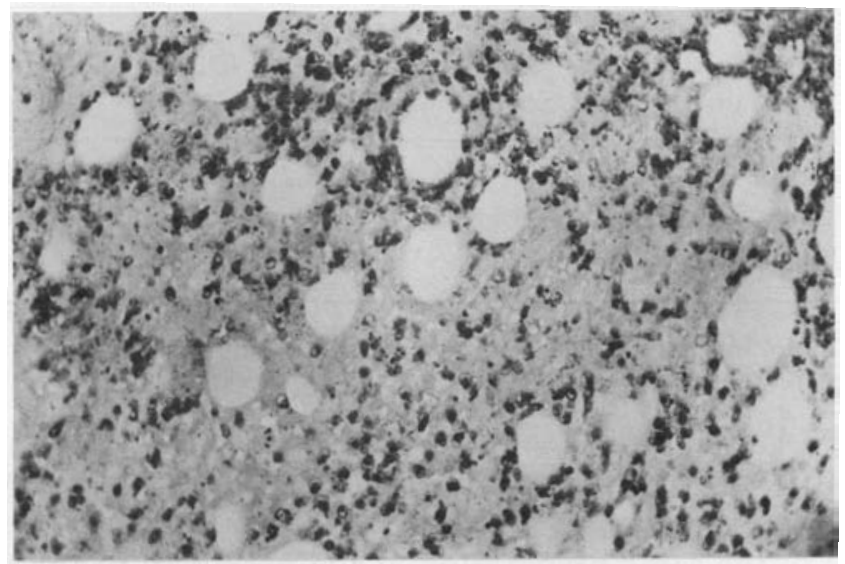

Figure 4. Bacterial antigen ingested by neutrophils in ENL lesion. Methenamine silver. $\times 175$.

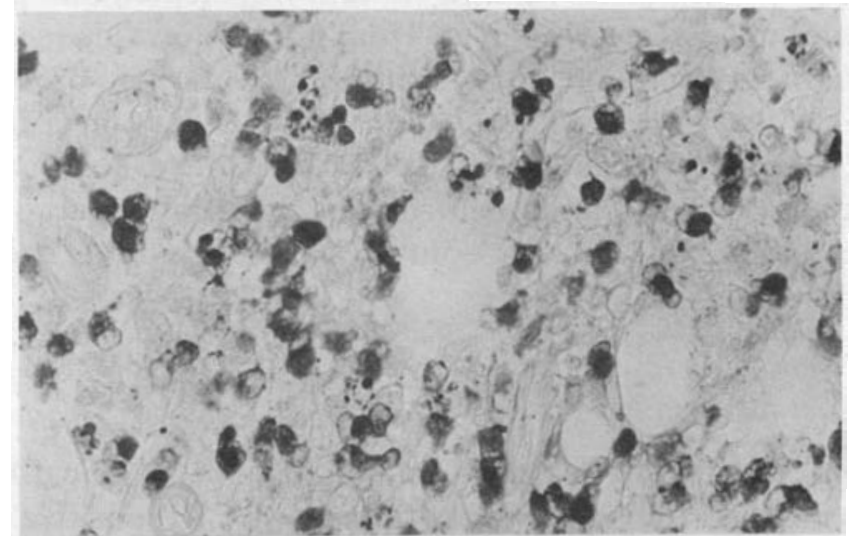

Figure 5. Mycobacterial antigen in neutrophils and macrophages of ENL lesion, demonstrated by mycobacterial BCG antigen. $\times 350$. 
neutrophils. $\beta$-lipoprotein appears to outline some bacillary rods, and occurs in the same area as CRP but is generally weaker.

\section{Antibody}

Most striking is the appearance of $\operatorname{IgG}$ and $\operatorname{IgM}$ in neutrophils and degenerating foamy macrophages which correspond to the cells containing $M$. leprae antigen. As a rule IgM appears first and is more prominent in macrophages containing fragmented bacilli. IgG is more marked in neutrophils and has the same granular or diffuse appearance as bacterial antigen demonstrated in these cells. In the later lesions, after the neutrophils have disappeared, there may be new macrophages containing $\mathrm{IgG}$ positive debris among the residual foam cells. Other foam cells containing bacterial debris remain intact with no intracellular antibody. Plasma cells and $\mathrm{B}$ lymphocytes are very numerous throughout the lesion and small capillaries are clearly outlined by several layers of these cells, indicating their haematogenous origin (Figure 6).

\section{Complement}

Complement, like antibody, is demonstrated in neutrophils. It is mainly $\mathrm{C}_{3}$ with some $\mathrm{C}_{1} \mathrm{q}$ and $\mathrm{C}_{3} \mathrm{~d}$. In later lesions macrophages that have ingested $\mathrm{IgG}$ coated bacilli also show $\mathrm{C}_{3}$, which is very marked also in the 'mat' of aggregated bacillary debris in the vacuoles of some superficial reactions.

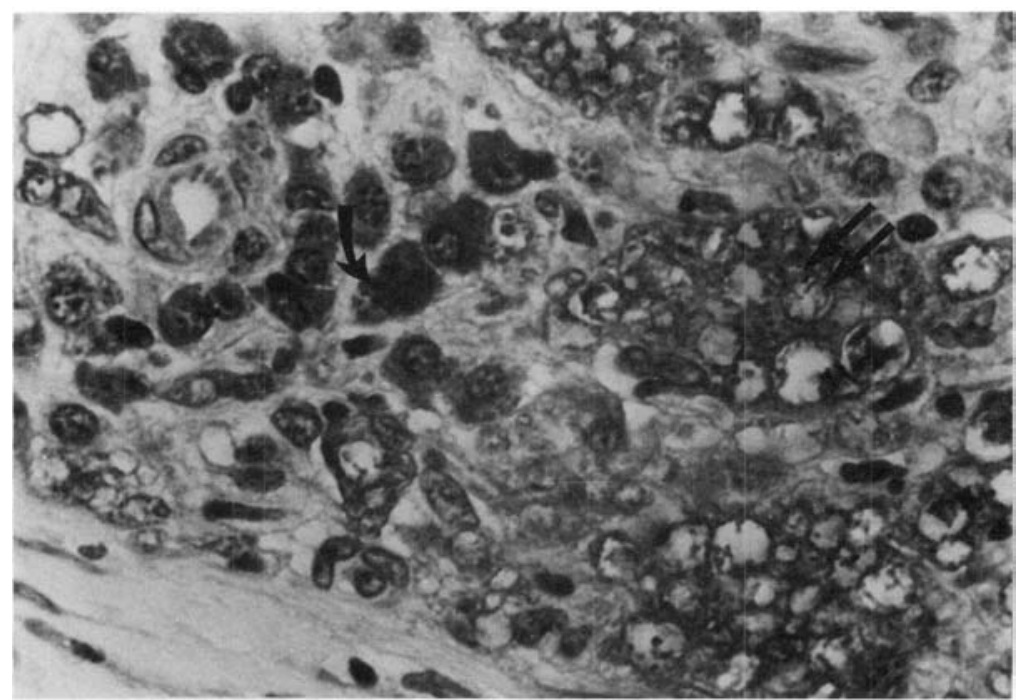

Figure 6. Plasma cells positive for $\operatorname{IgG}(\uparrow)$. Residual macrophages have bacilli coated with $\mathrm{IgG}(\uparrow \uparrow) . \times 525$. 
THE CONNECTIVE TISSUE AND SKIN STRUCTURES IN ENL

A most notable feature is the marked serous fibrinous exudate, associated with fibrinoid degeneration of collagen and elastic fibres, in and around the reacting areas. The degree of severity is variable. The exudate contains a few neutrophils and other inflammatory cells. Mast cells are a prominent feature. The small, medium-sized and even large blood vessels may be markedly altered. This acute reaction resolves and is followed by regeneration of connective tissue. However, the elastosis persists and in no biopsy of the New Guinea group examined is there any detectable return to normal of the elastic fibres. Macrophages are commonly seen associated with degenerative elastic fibres between the newly formed collagen bundles. Fibrous septa in the subcutaneous reactive areas are slow to heal.

High levels of $\mathrm{IgG}$ and $\mathrm{IgM}$, and variable amounts of complement $\mathrm{C}_{3}, \mathrm{C}_{4}, \mathrm{C}_{1} \mathrm{q}$ and $\mathrm{C}_{3} \mathrm{~d}$ are seen in the exudate and in fibrinoid degenerate connective tissue. Lysozyme, plasminogen and acute phase reactants CRP and to a lesser extent $\beta$-lipoprotein can be demonstrated in the exudate and are deposited on connective tissue fibrils undergoing fibrinoid change. The amount of lysozyme and plasma proteins detected varies directly with the severity of the exudate. SAP is most marked in the extracellular space, and in macrophages and neutrophils of the early acute reaction. In later lesions it is conspicuous in macrophages between the collagen bundles (Figure 7), which also contain IgG. The protease inhibitors $\alpha_{1}$-antitrypsin and $\alpha_{2}$-macroglobulin are seen in the extracellular space in the acute stage. Endogenous peroxidase is found in some neutrophils and extracellularly.

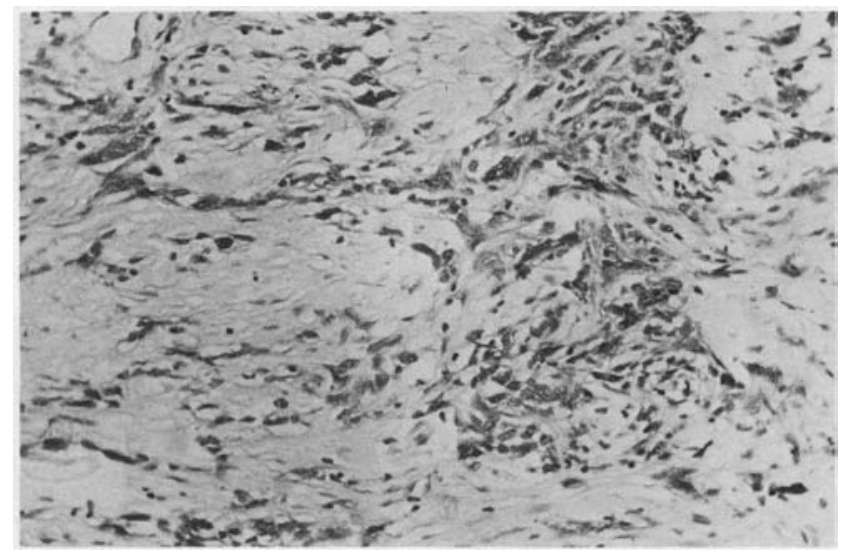

Figure 7. SAP in connective tissue exudate and macrophages of ENL lesion. Immunoperoxidase. $\times 175$. 


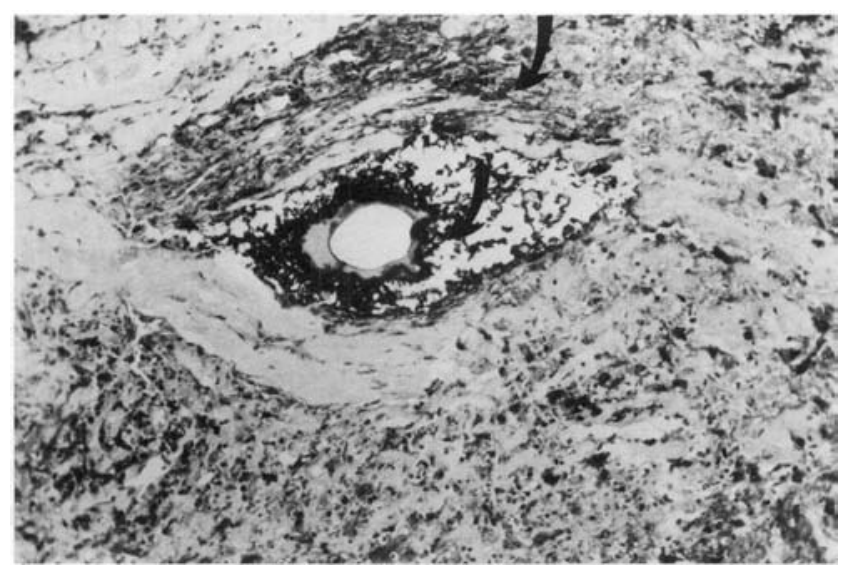

Figure 8. $C_{3}(\uparrow)$ is marked around medium-sized blood vessels and in exudate after the early infiltration stage. Immunoperoxidase. $\times 120$.

\section{Blood vessels}

No detectable immunological mediators or bacterial debris are detected in the vessels altered by the early inflammatory reaction. Later, with the appearance of serous exudate, small and medium-sized arteries are obliterated by swollen endothelium. At this time $\operatorname{IgG}, \operatorname{IgM}$ and $\mathrm{C}_{3}$, and diffuse bacterial debris stained by silver or anti-BCG serum, can be demonstrated in the endothelium, swollen muscle and adventitia of the vessel walls (Figure 8). Large vessels containing demonstrable acid-fast bacteria or debris become involved when the exudate is at its peak. IgG, IgM and $\mathrm{C}_{3}$ are then present in very large amounts in association with the adventitia, or more particularly in the immediate neighbourhood of the vessel.

\section{Nerve bundles}

Nerve bundles are involved equally in the reacting and non-reacting areas. Granular bacilli and acid-fast debris appear to be coated with $\operatorname{IgM}$ and complement. Lysozyme is marked in the interaxonal spaces, as also is $\mathrm{IgG}$, and CRP can be demonstrated.

\section{NON-REACTING LESIONS}

In control biopsies of lepromatous lesions at a comparable stage of activity or regression, CRP is bound to acid-fast bacilli or debris, which is nearly all intracellular. SAP is present in the phagocytic vacuole, and $\beta$-lipoprotein may produce a pale halo around the bacilli. There is no immunoglobulin bound to the 
bacilli. All immunological factors except CRP are present in smaller amounts than in reacting lesions. Inflammatory cells are scanty.

\section{Discussion}

The weakness of the generally accepted immune complex aetiology of ENL has been that it has not so far been possible to confirm the previous demonstration of complexes at reaction sites using the rather insensitive fluorescent antibody technique ${ }^{8}$ and indeed it is not always possible to demonstrate mycobacterial antigen by acid-fast staining methods. It is known, however, that whether the reaction takes place in the skin, ${ }^{12}$ synovia ${ }^{19}$ or in nerves ${ }^{20}$ residual lepromatous granulomata can be found at the reaction site.

In the present paper, we demonstrate that bacterial cell bodies, either intact or in fragments or diffuse debris, can invariably be demonstrated using the methenamine silver method, that this bacterial residue contains antigen which reacts with anti-BCG antiserum, and that the antigen is partly free as a result of the break-up of eff ete host-cell macrophages. This cellular disintegration and the attachment of ferritin-conjugated antibody to bacterial cytoplasm has already been demonstrated ultrastructurally. ${ }^{21}$ We demonstrate also that bacterial antigen, $\operatorname{IgG}$ and $\operatorname{IgM}$ and complement components are all present at the same sites, both extracellularly in the neighbourhood of macrophages and intracellularly in the polymorphs, which are the hallmark of the acute stage of ENL reactions. The immunoperoxidase staining of these immunological factors, other than antigen, was stronger in the reacting lesions than in non-reacting lepromatous lesions at a comparable stage of regression. It can be inferred, therefore, that ENL is associated with immune complexes of which Mycobacterium leprae antigen is a component, that this is a constant finding, and that extracellular immune complexes are not a demonstrable feature of non-reacting lesions.

ENL, though centred around a granuloma, is known to involve the connective tissue of the dermis ${ }^{22}$ causing fibrinoid change and disruption of the elastic tissue fibres which can be the main feature of the lesion..$^{23}$ In the present study the immunoperoxidase results produced a less clear cut distinction between these two variants of ENL than was apparent histologically. With the onset of oedema and fibrinoid change no bacterial antigen could be detected. This may be because it is degraded to an undetectable form, or because it is masked by the large amount of CRP, SAP and $\beta$-lipoprotein in the exudate. CRP is known to bind to microorganisms, ${ }^{24}$ and to activate the complement system. ${ }^{25}$ SAP binds to elastic, ${ }^{24}$ and $\beta$-lipoprotein may be involved in complex formation. ${ }^{26}$ However, CRP is present, bound to $M$. leprae, in equal amounts in reacting and non-reacting lepromatous lesions, and the antigen primarily involved in the connective tissue reaction is not established. The main role of CRP could be to 
elicit the inflammation required for resolution and repair, ${ }^{25}$ which would account for its association with collagen.

Vasculitis is sometimes conspicuous but only in about half of all ENL lesions. ${ }^{27,}{ }^{28} \mathrm{We}$ suggest it is not the cause but is secondary to ENL, developing as a result of immune complexes and inflammatory mediators entering the circulation from the lesion, to which the vasculitis is localized. An association between ENL and glomulonephritis has not been established. ${ }^{29}$ The response of ENL to thalidomide has been correlated with the presence in the lesions of immunoglobulin-containing cells. ${ }^{30}$ The fact that thalidomide is not effective in the treatment of vasculitis or Arthus reaction ${ }^{31}$ is further evidence against vasculitis playing a primary role in ENL.

There is much individual variation in the onset of ENL, from person to person and from one lesion to another. It is not possible to say precisely why one lesion reacts and another does not, but the events that culminate in a reaction may be as follows. The onset usually occurs after a period of therapy, or in a quiescent phase, and the onset is often preceded by a large diminution in the bacterial index. ${ }^{32}$ Circulating immunoglobulins are variable but higher in ENL than in non-reacting patients. ${ }^{33,}{ }^{34}$ In young active lesions there will probably be an excess of antigen though it is not all accessible. As the infection goes into regression the antibody-antigen ratio will rise at the same time that more antigen becomes free. It is known that the antigen-antibody ratio is critical in determining the form of a granuloma in mycobacterial disease, and that necrosis with polymorph infiltration is associated with antigen and antibody at equivalence. ${ }^{35}$ Our present results suggest that ENL may be precipitated slightly before equivalence is reached, i.e. at a small antigen excess, and that thereafter the antibody level continues to rise with an influx of lymphocytes in the late stage. The lesions which go into reaction, whether in skin or other tissues, are presumably those in which the amount of free antigen is appropriate to the antibody level at the site. The necrosis and oedema with which the reaction is associated could lead to the release and dispersal of further deposits of antigen, and in turn to more antibody production. Adjuvant would be provided by the release of lipid from disintegrating fat-filled macrophages, and by fat necrosis, if the reaction happened to be centred on a granuloma in the subcutis. CRP complexes may contribute to autostimulation. ${ }^{36,37}$ Thus there is probably a self-perpetuating element in the reaction.

The role of immune complexes in ENL and the histology of the reaction are analogous to the situation in an Arthus reaction, as many other workers have observed. The two reactions are, however, different in so far as Arthus ${ }^{38}$ and von Pirquet $^{39}$ were dealing with circulating soluble immune complexes. Although ENL is unlikely to be a unique phenomenon it is difficult to think of any exact counterpart in other diseases. It is perhaps conditional on the slow degradation of large amounts of antigen of low immunogenicity. 


\section{Acknowledgements}

We are much indebted to Mrs Deborah F Russell and Miss Susan Langeveld for their invaluable and expert technical assistance. Grateful thanks are due to Dr Ross StC Barnetson for reading the manuscript and for useful discussions.

\section{References}

1 Jopling WH. Handbook of Leprosy, 2nd ed. Heinemann, 1981.

2 Moran CJ, Turk JL, Ryder G, Waters MFR. Evidence for circulating immune complexes in lepromatous leprosy. Lancet, 1972, ii: 572-3.

${ }^{3}$ Rojas Espinosa O, Mendez-Navarette I, Estrada-Parra S. Presence of $\mathrm{C}_{1} \mathrm{q}$ reactive immune complexes in patients with leprosy. Clin exp Imm, 1972; 12: 215-23

${ }^{4}$ Gelber RH, Drutz DJ, Epstein WV, Fasal P. Clinical correlates of $\mathrm{C}_{1} \mathrm{q}$ precipitating substances in sera of patients with leprosy. Amer J Trop Med Hyg, 1974; 23: 471-5.

5 Bjorvatn B, Barnetson RStC, Kronvall G, Zubler RH, Lambert PH. Immune complexes and complement hypercatabolism in patients with leprosy. Clin exp Imm, 1976; 26: 388-96.

${ }^{6}$ Iveson JMI, McDougall AC, Leatham AJ, Harris HJ. Lepromatous leprosy presenting with polyarteritis, myositis and immune complex glomerulonephritis. $\mathrm{Br}$ Med J, 1975; ii: 619-21.

7 Date A, Johny KV. Glomerular subepithelial deposits in lepromatous leprosy. Amer J Trop Med Hyg, 1975; 24: 853-6.

8 Wemambu SNC, Turk JL, Waters MFR, Rees RJW. Erythema nodosum leprosum: a clinical manifestation of the Arthus phenomenon. Lancet, 1969; ii: 933-5.

9 Turk JL. Immunological aspects of clinical leprosy. Proc Roy Soc Med, 1970; 63: 1053.

10 Waters MFR, Turk JL, Wemambu SNC. Mechanisms of reactions in leprosy. Int J Lepr, 1971; 39: 417-28.

11 Bjune G. Significance of immune reactions in leprosy. J Oslo City Hosp, 1980; 30: 81-100.

12 Ridley DS. Skin Biopsy in Leprosy. Histological Interpretation and Clinical Application. Basle: Documenta Geigy, 1977.

${ }^{13}$ Ridley DS, Ridley MJ, Russell D. An immunoperoxidase study through the spectrum of leprosy. Int J Lepr, 1982; 50: 11-19.

14 Ridley MJ, Russell D. An immunoperoxidase study of immunological factors in high immune and low resistance granulomas in leprosy. $J$ Path, 1982; 137: 149-57.

15 Ridley DS, Ridley MJ. Fixation of skin biopsies. Lepr Rev, 1975; 309-10.

${ }^{16}$ Curran RC, Gregory J. Effects of fixative and processing on immunohistochemical demonstration of immunoglobulin in paraffin sections of tonsil and bone marrow. J Clin Path, 1980; 33: $1047-57$.

17 Sternberger LA, Hardy PH Jr, Cuculis JJ, Meyer HG. The unlabelled antibody method of immunohistochemistry. J Histochem Cytochem, 1970; 18: 315.

18 Mason DY, Bell JI, Christensson B, Biberfield P. An immunohistological study of human lymphoma. Clin exp Imm, 1980; 40: 235-48.

19 Karat ABA, Karat S, Job CK, Furness MA. Acute exudative arthritis in leprosy: a rheumatoid-arthritis like syndrome in association with erythema nodosum leprosum. $\mathrm{Br} \mathrm{Med}$ $J, 1967$; ii: $770-2$.

20 Job CK, Bhaktaviziam C. Nerve abscess in lepromatous leprosy. Report of a patient. Lepr Rev, 1967; 38: 243.

${ }^{21}$ Okada S, Nakai E, Narita M, Takahashi S, Jarada N. Electron microscope study of erythema nodosum leprosum. Int J Lepr, 1974; 42: 33-7.

22 Ridley DS, Wise MJ. Reaction of the dermis in leprosy. Int J Lepr, 1964; 32: 24-36. 
${ }^{23}$ Ridley DS, Rea TH, McAdam KPWJ. The histology of erythema nodosum leprosum. Variant forms in New Guineans and other ethnic groups. Lepr Rev, 1981; 52: 65-78.

${ }^{24}$ Pepys M. Serum C-reactive protein, serum amyloid $\mathrm{P}$ component and serum amyloid A protein in autoimmune disease clinics. Imm \& All, 1981, vol 1, No. 1. Saunders.

${ }_{25}^{5}$ Pepys MB. C-reactive protein and the acute phase response. Nature, 1982; 296: 12.

${ }^{26}$ Smith GW, Hannah SF, Scott PJ, Simpson IJ. Immune complex-like activity associated with abnormal serum lipoprotein in systemic lupus erythematosus. Clin exp Imm, 1982; 48: 8-16.

27 Job CK, Gude S, Macaden VP. Erythema nodosum leprosum. A clinico-pathologic study. Int J Lepr, 1964; 32: 177-84.

${ }^{28}$ Mabalay MC, Helwig EB, Tolentino JG, Binford CH. The histopathology and histochemistry of erythema nodosum leprosum. Int J Lepr, 1965; 33: 28-49.

$29 \mathrm{Ng}$ WL, Scollard DM, Hua A. Glomerulonephritis in leprosy. Amer J Clin Path, 1981; 76: 321-9.

${ }^{30}$ Faber WR, Leiker DL, Cormane RH. Immunofluorescence studies in reactional leprosy with relevance to treatment. Arch Derm Res, 1978; 261: 323-30.

${ }^{31}$ Ulrich M, de Salas B, Convit J. Thalidomide in experimental Arthus and anaphylactic reactions. Int J Lepr, 1971; 39: 131-5.

32 Ridley DS. Bacteriologic study of erythema nodosum leprosum. Int J Lepr, 1960; 28: 254-66.

${ }^{33}$ Ulrich M, Pinardi ME, Convit J. A study of antibody response in leprosy. Int J Lepr, 1969; 37: 22-7.

34 Reichlin M, Pranis RA, Gelber RH, Rees RJW, Taverne J, Turk JL. Correlation of euglobulin immunoglobulin $\mathrm{G}$ levels with erythema nodosum leprosum in lepromatous leprosy. Clin Imm Immunopath, 1977; 8: 335-44.

35 Ridley MJ, Marianayagam Y, Spector WG. Experimental granulomas induced by mycobacterial BCG/anti-BCG complexes in rats. $J$ Path, 1982; 136: 59-72.

${ }^{36}$ Parish WE. Studies on vasculitis. VII. C-reactive protein as a substance perpetuating chronic vasculitis. Clin Allergy, 1976; 6: 543-50.

37 de Beer FC, Soutat AK, Baltz ML, Trainer I, Feinstein AJ, Pepys MB. Low density lipoprotein and very low density lipoprotein are selectively bound by aggregated C-reactive protein. $J$ exp Med, 156: 230-42.

38 Arthus M. Injections repetées de serum de cheval chez la lapin. Compt rend soc Biol, 1903; 55: 817.

39 Von Pirquet C. Die Serum Krankheit (trans 1951). Baltimore: Williams \& Williams Co, 1905. 